\title{
Intramuscular 30\% polymethylmethacrylate (PMMA) implants in a non-protein vehicle: an experimental study in rats
}

\author{
Implante intramuscular de polimetilmetacrilato (PMMA) 30\%, associado a \\ veículo não-proteico: estudo experimental em ratos
}

\author{
Edela Puricelli ${ }^{1}$ \\ Almir Moojen NÁcul ${ }^{2}$ \\ Deise Ponzoni ${ }^{3}$ \\ Adriana CorsetTi ${ }^{4}$ \\ Laura de CAmpos \\ HILDEBRAND $^{5}$ \\ Denis Souto VAlente ${ }^{6}$
}

Study conducted at the Instituto de Biociências of Universidade Federal do Rio Grande do Sul, Porto Alegre, RS, Brazil.

Submitted to SGP (Sistema de Gestão de Publicações/Manager Publications System) of RBCP (Revista Brasileira de Cirurgia

Plástica/Brazilian Journal of Plastic Surgery).

Received: April 8, 2011 Accepted: July 16, 2011

\begin{abstract}
Introduction: In the present study, the stability and biocompatibility of a $30 \%$ polymethylmethacrylate (PMMA) filling material implanted in the masseter muscle of rats were investigated according to the cytologic characteristics presented in the graft versus host reaction. Methods: The study included 20 rats, which were divided into 4 groups: groups I, II, III, and IV corresponded to animals evaluated $7,14,45$, and 60 days after surgery, respectively. The implant was placed in the right masseter muscle at the level of the mandibular angle. Results: After 7 days, lymphoplasmacytic inflammatory infiltrates, a fibrous capsule, a large number of neutrophils, macrophages, and exudate were observed. The second group (14 days) showed granulation tissue composed of a lymphoplasmacytic inflammatory infiltrate, newly formed vessels, and a fibrous capsule. However, the second group also exhibited regeneration of the muscle fibers, and a decreased number of neutrophils and exudate. After 45 and 60 days, the inflammatory infiltrate decreased in intensity compared to the first 2 groups. Conclusions: The inflammatory reaction caused by PMMA is transient and does not compromise the function and the shape of the masseter muscle tissue, suggesting that PMMA is biocompatible.
\end{abstract}

Keywords: Biocompatible materials. Polymethyl methacrylate. Masseter muscle.

\section{RESUMO}

Introdução: Este trabalho busca avaliar, em ratos, a estabilidade e a biocompatibilidade de um material de preenchimento à base de polimetilmetacrilato (PMMA) a 30\% implantado no músculo masseter, por meio do padrão, e a organização reacional no tecido receptor. Método: Foram utilizados 20 ratos, divididos em quatro grupos: grupo I, que correspondeu ao período de 7 dias de pós-operatório; grupo II, de 14 dias; grupo III, de 45 dias; e grupo IV, de 60 dias. O implante foi realizado no músculo masseter direito, na região do ângulo da mandíbula. Resultados: No período de 7 dias, observou-se presença de infiltrado inflamatório linfoplasmocitário, com formação de cápsula fibrosa e presença de grande número de neutrófilos, macrófagos e formação de exsudatos. Em 14 dias, observou-se a formação de um tecido de granulação composto por infiltrado inflamatório linfoplasmocitário, vasos de neoformação e cápsula fibrosa. Porém, nesse tempo experimental, nota-se a regeneração das fibras musculares e a diminuição do número de neutrófilos e exsudatos. Após 45 dias e 60 dias, observou-se, no tecido muscular, diminuição da intensidade do infiltrado inflamatório, comparativamente aos tempos experimentais anteriores. Conclusões: A reação inflamatória provocada pelo PMMA é transitória e não compromete as funções e o contorno desse tecido muscular, o que sugere que o PMMA é biocompatível.

Descritores: Materiais biocompatíveis. Polimetilmetacrilato. Músculo masseter.

1. PhD at the University of Dusseldorf, Germany, Master's Degree and Doctorate in Odontological Clinics, Professor of Oral Maxillofacial Surgery and Traumatology (CTBMF) and in Oral Pathology of the Odontology College of the Universidade Federal of Rio Grande do Sul (FO-UFRGS), Coordinator of the CTBMF Unit of the Clinics Hospital of Porto Alegre (HCPOA), Porto Alegre, RS, Brazil.

2. Plastic Surgeon, full member of the Brazilian Society for Plastic Surgery (BSPS), former assistant professor of the Discipline of Plastic Surgery of the Faculdade de Ciências Médicas da Universidade de Caxias do Sul, Porto Alegre, RS, Brazil.

3. Surgeon Dentist, Master's Degree in Odontological Clinics/Oral Maxillofacial Surgery and Traumatology at UFRGS and PhD in Odontology/Oral Maxillofacial Surgery and Traumatology at the Pontificie Universidade Católica do Rio Grande do Sul (PUCRS), associated professor at FO-UFRGS and at HCPOA, Porto Alegre, RS, Brazil.

4. Master's Degree in Odontological Clinics and PhD student of Odontological Clinics, concentration area in CTBMF of the UFRGS, surgeon dentist from UFRGS, Porto Alegre, RS, Brazil.

5. PhD student and Master in Oral Pathology at UFRGS, surgeon-dentist from UFRGS, Porto Alegre, RS, Brazil.

6. Plastic Surgeon, scientific director of the Clínica Nácul, Porto Alegre, RS, Brazil. 


\section{INTRODUCTION}

The need for oral maxillofacial reconstruction has increasingly motivated the search for biomaterials for biological use ${ }^{1}$. These materials must be inert to body fluids, easily manipulated, and preferably permanent ${ }^{2}$.

Biomaterials can be classified as bio-tolerable, bioinert, bioactive, or bioabsorbable ${ }^{3}$. Biomaterials possessing a larger number of these properties therefore are closer to the ideal material.

In the search for new products, Puricelli et al. ${ }^{4}$ (1999) performed subperiosteal implantation of a hybrid polyurethane polymer from castor beans in the rat mandibular angle. The results showed the formation of a supraperiosteal fibrous capsule, without signs of rejection, exposure, or mobility of the implant. The bone surface showed some signs of new bone formation. These results show the versatility of the physiological behavior of this polymer, combining bio-tolerability and bioactivity.

Synthetic formulations that consist of polymers can be predominantly qualified as bio-tolerable. The thickness of the fibrous capsule formed is inversely proportional to the tolerability of the material.

Polymethylmethacrylate (PMMA) $\left[\mathrm{CH}_{2}=\mathrm{C}\left(\mathrm{CH}_{3}\right)\right.$ $\mathrm{COOCH}_{3}$ ] was first synthesized successfully in $1902^{5}$. Since 1945, this material, which is widely used in dentistry for the preparation of dental prostheses, has been progressively used in oral maxillofacial surgery ${ }^{6}$. PMMA is also used in other surgical specialties and is recognized as an excellent material for hip prostheses, reconstruction of the skull, and intraocular lenses. PMMA is also characterized as nonabsorbable or permanent ${ }^{7}$.

In plastic surgery, PMMA is used as a filling material, and is indicated for rejuvenation techniques. Its injection will increase local volume. The tendency to protrude through the skin; potential risk of migration and dispersion; formation of fibrotic nodules and granuloma (foreign body reaction), phagocytosis, and hematomas in the area of implantation; and epithelial pigment changes, among others, are considered as side effects ${ }^{8,9}$.

PMMA has been applied for the correction of facial wrinkles and filling of the labial, jugal, malar, zygomatic and palpebral regions, mandible line. It is also recommended for use in procedures on other body areas such as hands, augmentation and reconstruction of nipples, and lipodystrophy ${ }^{8,10,11}$. Its first formulation was developed by Gottfried Lemperle and contained a portion of PMMA dispersed in collagen. This was followed by other associations with homogenous non-biodegradable microspheres suspended in different biocompatible vehicles. The dimension of the particle, which ranges in average from 30 to $40 \mu \mathrm{m}$ in diameter, hinders the process of phagocytosis $^{12-14}$.
Nácul ${ }^{15}$ in 2005 proposed a new injectable biomaterial prepared by suspending PMMA microspheres, hydroxyethylcellulose, methylparaben, propylparaben, water for injection (New Plastic).

The facial muscles include masticatory muscles, and injury to these muscles can occur by various mechanisms, including direct trauma, ischemia, or laceration. Musculoskeletal healing and repair involve the formation of scar tissue, which is different from the tissue present before the injury ${ }^{16}$. Injuries to the muscle tissue damage the structure of the sarcoplasmic reticulum (endomysium, perimysium, and epimysium) that is involved in the muscle contraction process.

The healing process of an injured muscle follows a constant pattern, irrespective of the underlying cause (contusion, tension, or laceration). Three phases are identified in the healing process: inflammation, regeneration, and fibrosis. Muscle injury causing the sectioning of blood vessels triggers a cascade of cellular reactions that constitute the inflammatory process, which is considered a protective response to tissue damage. This initial inflammatory phase is critical for the recovery process. The inflammatory cell population can persist for days or weeks as long as muscular regeneration and repair are taking place. However, the acute inflammatory reaction lasts from 6 to 24 hours after the trauma. Inflammation is the process by which leukocytes and other phagocytic cells and exudates are transported to the injured tissue. The objective of this cellular reaction is to locate and eliminate the byproducts of the lesion (blood and damaged cells) by phagocytosis in preparation for the tissue repair process. This stage is characterized by local vascular effects, disturbances in the exchange of fluids, and migration of leukocytes from blood to tissues.

The healing process begins approximately 3 days after the injury, and stabilization occurs after 2 weeks. Full restoration can take 15 to 60 days for completion ${ }^{16-18}$.

Allen ${ }^{19}$, in a longitudinal study in humans, observed the cellular reactions to the injection of two-phase polymer implants with a carrier vehicle containing textured inert solid silicone particles through a cannula in the inguinal region. After 24 hours, a predominance of neutrophils and small round cells was observed in the area, and within 48 hours, monocytes predominated. The formation of giant cells in response to the foreign body was observed after 7 days. Two weeks later, the cellular response was moderate, and within the following 4 weeks, the monocytes differentiated into epithelioid cells, with the emergence of fibroblasts. The 6-week time point was characterized by a foreign-body giant cell reaction and increased deposition of collagen, and at 8 weeks, the chronic inflammatory cells were dispersed throughout the massive deposition of collagen. Thereafter, the cellular reaction to the foreign 
body remained stable and after 6 months, giant cells and a small degree of cellular response were observed, with a reduced amount of dense collagen and the conversion of fibroblasts into fibrocytes.

Unlike the usual superficial deposition, which takes place just under the skin, bioplasty with the application of PMMA in deep plane, especially at intramuscular level, allows more natural modeling. The filling material is deposited through a microcannula introduced into the desired tissue plane. The bioplasty therefore enables the inclusion of areas adjacent to the periosteum and perichondrium as well as the intramuscular plane, in addition to the subcutaneous areas. In the face, the muscular areas that can be molded are the mentum, lower lip depressor, the angle of the mouth, and the masseter. The result can be considered definitive approximately 2 months after the bioplasty, when growth in that region due to interaction of the implant with the tissue structures is no longer expected ${ }^{10}$.

The present study used rats as a model to evaluate the local stability and biocompatibility of $30 \%$ PMMA in a non-protein vehicle implanted in the intramuscular masseteric plane at the mandibular angle.

\section{METHODS}

The present study was an experimental, in vivo, and controlled study with randomized sampling. A total of 20 Wistar rats (Rattus norvegicus albinus) were used. The rats were young adults, weighing approximately $400 \mathrm{~g}$, and they were maintained at the animal house of Instituto de Biociências of UFRGS, Porto Alegre, RS, Brazil.

The biomaterial used consisted of PMMA microspheres, hydroxyethylcellulose, methylparaben, propylparaben, water for injection (New Plastic).

The animals were placed under general anesthesia, and the right masseter area was shaved. The experimental protocol followed a minimally invasive procedure. A beveled micropuncture needle was used to puncture the skin for introduction of a rhombus cannula $(25 \times 0.8 \mathrm{~mm})$. A tunnel was created with the cannula towards the angle of the jaw, and the material was implanted in the muscle, in the path of withdrawal of the cannula. The amount of material deposited corresponded to a volume of $0.33 \mathrm{ml}$, as measured by the application pistol. After the deposition, the area was massaged to facilitate the distribution of the material.

The animals corresponding to each group were euthanized on days $7,14,45$, and 60 after surgery for sample collection, according to the recommendations of the Commission of Health Research and Ethics of the Group of Research and Post-Graduation of the Clinics Hospital of Porto Alegre - Normative Resolution 04/97. An autopsy was performed, and the right masseter muscle of the animal was removed, keeping a safety margin of $0.5 \mathrm{~cm}$ around the area of interest.

The muscle samples were processed for routine hematoxylin-eosin staining. The microscopic study was based on a qualitative description of the tissues.

\section{RESULTS}

The light microscopy results of the tissue sections corresponded to the experimental periods of 7, 14, 45, and 60 days. At 7 days after injection of PMMA, the presence of a lymphocytic inflammatory infiltrate, and the formation of an incomplete fibrous capsule surrounding the material were observed. In addition, the presence of a large number of neutrophils and macrophages and the development of exudate were noted. In some regions, the macrophages joined together to form foreign body-type multinucleated giant cells (Figure 1). The muscle tissue showed signs of degeneration, probably due to the intense local inflammatory process (Figure 2). The local inflammatory reaction was caused by the application of a foreign material to the body, and was not associated with a significant health risk to the individual as it was not a systemic process.

Day 14 after the injection of PMMA was marked by the formation of granulation tissue composed of a lymphoplasmacytic inflammatory infiltrate, newly formed vessels, and a fibrous capsule. However, the regeneration of muscle fibers and a decrease in the number of neutrophils and exudate were also noted at this time, and the characteristic structure of the PMMA remained unchanged (Figure 3).

Forty-five days after the PMMA injection into the muscle tissue, there was a decrease in the intensity of the inflammatory infiltrate in comparison to the previous experimental

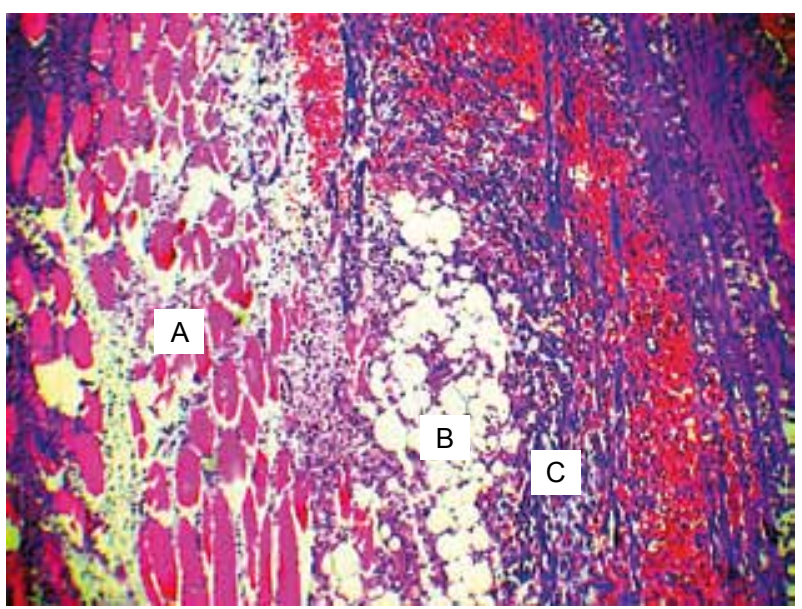

Figure 1 -Muscle Tissue (A), PMMA (B) surrounded by inflammatory infiltrate with macrophages, multinucleated giant cells $(\boldsymbol{C})$, and bleeding (7 days, $400 \times)$. 


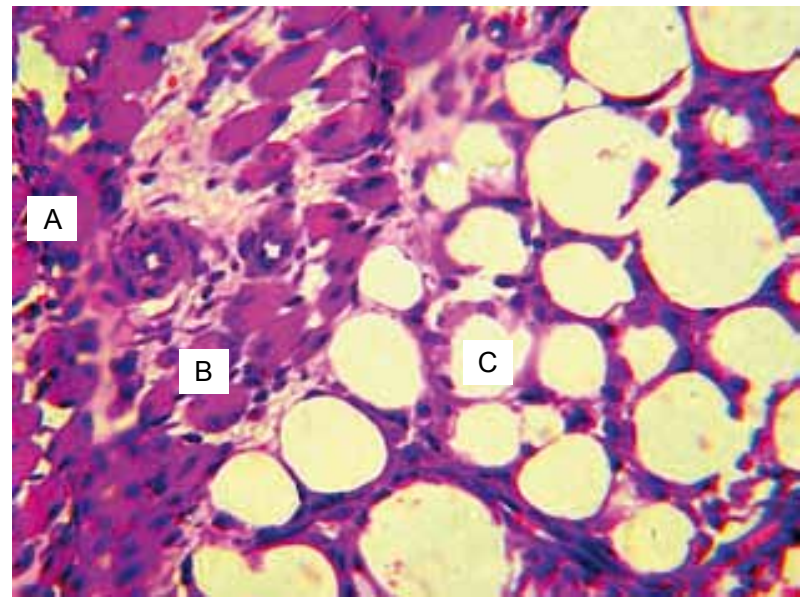

Figure 2 - Inflammatory infiltrate with neutrophils $(\boldsymbol{A})$, degenerative muscle tissue $(\boldsymbol{B})$, and PMMA (C) (7 days, 1,000×).

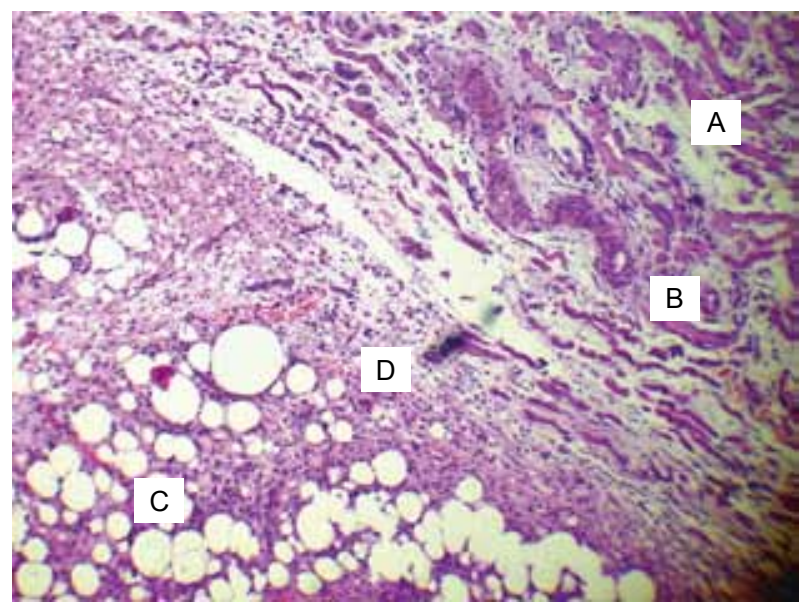

Figure 3 -Degenerative muscle tissue $(\boldsymbol{A})$, neoangiogenesis $(\boldsymbol{B})$, and PMMA (C) surrounded by granulation tissue (D) (14 days, 400×).

periods, and the muscle tissue fibers showed a normal appearance without changes in form or composition. The PMMA remained in place, without alterations in its configuration (Figure 4). The 60-day time point was characterized by the incorporation of the PMMA between the muscle fibers with no changes to the morphology of this tissue and the absence of an inflammatory infiltrate in the filling material (Figure 5).

\section{DISCUSSION}

The possibility of using biomaterials for the reconstruction of certain regions of the human body has motivated a significant amount of research in this area ${ }^{1}$.

PMMA, an alloplastic material, has been shown to be suitable for implantation into muscle tissue based on its

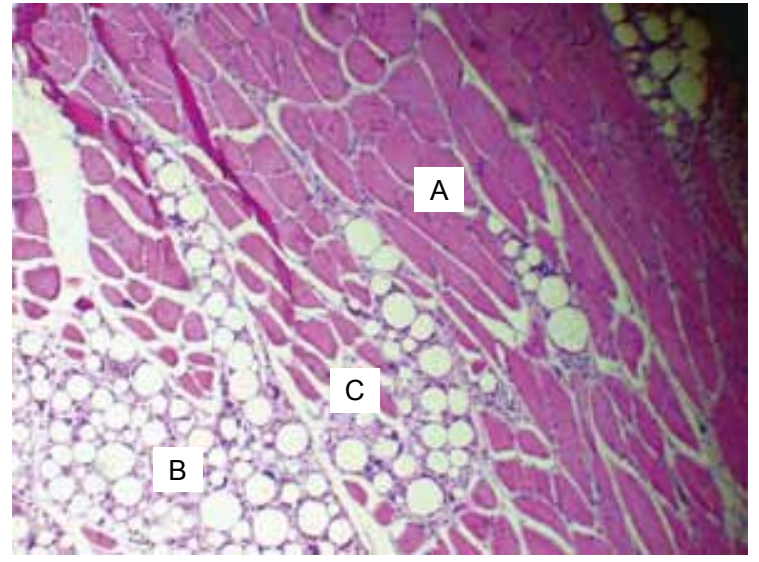

Figure 4-Normal muscle tissue (A) and PMMA (B) surrounded by fibrous connective tissue with mild inflammatory infiltrate $(\boldsymbol{C})(45$ days, $400 \times)$.

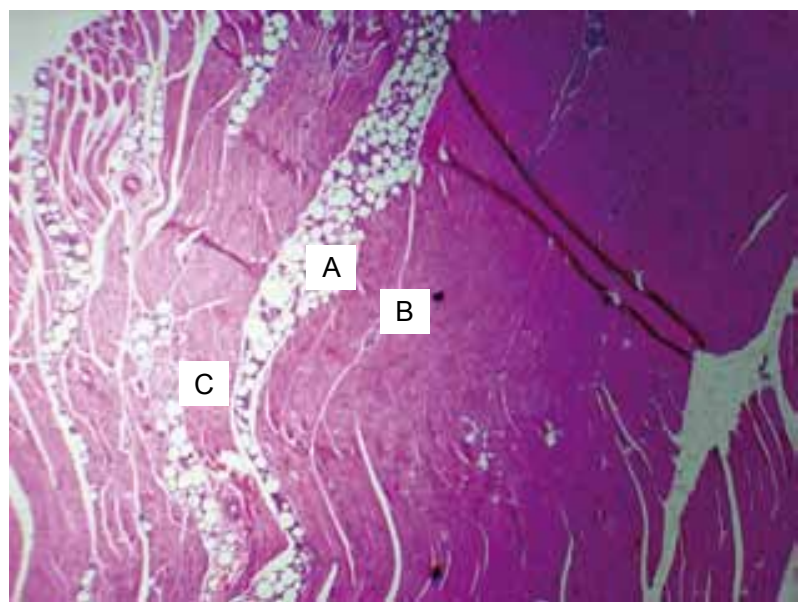

Figure 5 - PMMA (A), healthy muscle tissue $(\boldsymbol{B})$, and neurovascular elements $(\boldsymbol{C})(60$ days, $200 \times)$.

properties as a biocompatible, stable, non-reabsorbable material, which fulfills the requirements of an ideal material as recommended in the literature ${ }^{2,9,20-23}$.

The inflammatory reaction is a normal process caused by the injection of a foreign material into an organism. Even materials classified as biocompatible can cause this type of reaction after the first day of injection ${ }^{19}$. Therefore, the intense inflammatory reaction observed in the tissue sections of animals examined after 7 and 14 days in this study can be considered normal.

Similar to the findings of Puricelli et al. ${ }^{4}$ in response to the implantation of a hybrid castor bean polyurethane polymer in the region of the mandibular angle in rats, a fibrous capsule was formed around the applied material in the absence of a foreign body reaction. 
Skeletal muscles have striations in the fibers. PMMA has been applied in the intramuscular plane in the mentum area in order to increase the volume seen pushing forwards, over the mentalis muscle, and improve the contour of the lower lip (notably involving the depressor anguli oris and the depressor labii inferioris), angle of the mouth, line, and angle of the jaw (masseter muscle) $^{14}$. PMMA injected into the masseter muscle of rats remained stable, and maintained its conformation without altering the organization of the receptor muscle.

The cannula used for the deposition of the material is blunt to avoid intravascular injection and nerve damage, as well as cutting or tearing of the muscle fibers, penetrating by divulsion. Muscle tissue has a low capacity for regeneration, which is mediated by satellite cells that proliferate by mitotic division when activated, merging together to form new skeletal fibers. Blood vessels penetrate the muscle through the connective tissue septa, forming extensive networks of capillaries. Injury to these networks causes bleeding of a volume compatible with the local lesion, which is not associated with a risk of hematoma. Macrophages, which can live for months in specific tissues, are derived from bone marrow stem cells that divide, producing monocytes that circulate in the blood. In a second step, these cells cross the walls of capillaries and pericytic venules and penetrate the connective tissue, where they mature and acquire the morphological characteristics of macrophages. Thus, monocytes and macrophages are the same cells at different stages of maturation, and they do not represent adverse reactions in long periods of observation.

\section{CONCLUSIONS}

The results of the histological analysis and the methodology used in this study led to the following conclusions:

- The inflammatory response caused by the injection of PMMA in the muscle tissue of rats is transient and does not compromise the functions and the contour of the treated tissue.

- PMMA is biocompatible and maintains its structural conformation after application in the masseter muscle of animals.

\section{REFERENCES}

1. Puricelli E. Retenção dentária: novos conceitos no tratamento ortocirúrgico. In: Puricelli E, ed. Atualização na clínica odontológica: a prática da clínica geral. São Paulo: APCD; 1998. p.1-28.
2. Rubin JP, Yaremchuk MJ. Complications and toxicities of implantable biomaterials used in facial reconstructive and aesthetic surgery: a comprehensive review of the literature. Plast Reconstr Surg. 1997;100(5):1336-53.

3. Hench LL, Wilson J. Introduction to bioceramics. Singapore: World Scientific Publishing; 1993. p. 1-15.

4. Puricelli E, Baraldi CE, Ponzoni D, Peschke R. Estudo histológico do polímero poliuretano da mamona implantado no ângulo mandibular de ratos. Rev Fac Odontol. 1999;40(1):37-40.

5. Willert HG, Buchhorn G. Knochenzement: Werkstoff, Klinische Erfahrungen, Weiterentwicklungen. Bern: Huber; 1987.

6. Puricelli E. Bioplastia na cirurgia e traumatologia bucomaxilofacial. In: Nácul AM, ed. Bioplastia: a plástica interativa. São Paulo: Editora Santos; 2007. p. 197-216.

7. Hoffmann C, Schuller-Petrovic S, Soyer HP, Kerl H. Adverse reactions after cosmetic lip augmentation with permanent biologically inert implant materials. J Am Acad Dermatol. 1999;40(1):100-2.

8. Lemperle G, Gauthier-Hazan N, Lemperle M. PMMA-Microspheres (Artecoll) for long-lasting correction of wrinkles: refinements and statistical results. Aesthetic Plast Surg. 1998;22(5):356-65.

9. Lemperle G, Morhenn V, Charrier U. Human histology and persistence of various injectable filler substances for soft tissue augmentation. Aesthetic Plast Surg. 2003;27(5):354-66.

10. Nácul AM. Bioplastia: a plástica interativa. São Paulo: Ed. Santos; 2007. $310 \mathrm{p}$.

11. Gonella HA, Barbosa MAA, Marques BPA, Orgaes FAFS, Oliveira RR. Avaliação da utilização do polimetilmetacrilato na correção das lipodistrofias faciais associadas à terapia anti-retroviral em pacientes HIV positivos. Rev Soc Bras Cir Plást. 2007;22(1):24-9.

12. Hertzog B. Artecoll: historia, composición y aspectos histológicos, técnica de inyección, comparación con los otros productos. J Méd Estét Cir. 1996;24(96):253-7.

13. Morhenn VB, Lemperle G, Gallo RL. Phagocytosis of different particulate dermal filler substances by human macrophages and skin cells. Dermatol Surg. 2002;28(6):484-90.

14. Nahas FX, Barbosa MVJ, Ferreira LM. Biomateriais injetáveis. In: Nácul AM, ed. Bioplastia: a plástica interativa. São Paulo: Ed. Santos; 2007. p. $15-22 . \mathrm{a}$

15. Nácul AM. Contour of the lower third of the face using an intramuscularly injectable implant. Aesthetic Plast Surg. 2005;29(4):222-9.

16. Järvinen TA, Järvinen TL, Kääriäinen M, Kalimo H, Järvinen M. Muscle injuries: biology and treatment. Am J Sports Med. 2005;33(5):745-64.

17. Tidball JG. Inflammatory processes in muscle injury and repair. Am J Physiol Regul Integr Comp Physiol. 2005;288(2):R345-53.

18. Toumi H, Best TM. The inflammatory response: friend or enemy for muscle injury? Br J Sports Med. 2003;37(4):284-6.

19. Allen $\mathrm{O}$. Response to subdermal implantation of textured microimplants in humans. Aesthetic Plast Surg. 1992;16(3):227-30.

20. Eppley BL, Sadove AM, German RZ. Evaluation of HTR polymer as a craniomaxillofacial graft material. J Plast Reconstr Surg. 1990;86(6):108592.

21. Salman L, Kinney LA. Clinical response of hard tissue replacement (HTR) polymer as an implant material in oral surgery patients. J Oral Implantol. 1992;18(1):24-8.

22. Froum SJ. 2 1/2 Year bone block study comparing HTR polymer, HA and DFDB. New York: HTR Symposium, New York University, October 15; 1993.

23. Passi P, Girardello GB, Piattelli A, Scarano A. HTR polymer grafts with osseointegrated implants: a histological study in humans. Oral Surg. 1996;3. Disponível em: http://www.imnr.ro/retebdent/Info/HTR\%20polymer\%20grafts\%20with\%20osseointegrated\%20implants.pdf Acesso em: $30 / 3 / 2011$

\section{Correspondence to:}

